\title{
Combined effects of cadmium and salinity on development and survival of garpike eggs*
}

\author{
H. von Westernhagen ${ }^{1}$, V. Dethlefsen ${ }^{2}$ \\ $\&$ H. RosEnTHAL ${ }^{1}$ \\ 1 Biologische Anstalt Helgoland (Zentrale); \\ Hamburg 50, Federal Republic of Germany, \\ and \\ 2 Institut für Küsten- und Binnenfischerei; \\ Hamburg 50, Federal Republic of Germany
}

\begin{abstract}
KURZFASSUNG: Kombinierte Wirkungen von Cadmium und Salzgehalt auf Entwicklung und Uberleben von Hornhechteiern. Laichreife Hornhechte (Belone belone L.) wurden im Frühjahr bei Travemünde (Ostsee) gefangen. Die Eier wurden in unkontaminiertem Seewasser von 15,25 und $35 \%$ Salzgehalt und etwa $15^{\circ} \mathrm{C}$ befruchtet und nach 3 Std. in Cadmiumkontaminiertes Erbrütungswasser überführt. Neben den Kontrollversuchen wurden Erbrütungsexperimente mit folgenden Cadmiumkonzentrationen in den 3 Salzgehaltsstufen durchgeführt: 0,$05 ; 0,1 ; 0,5 ; 1,0 ; 2,0$ und $5,0 \mathrm{ppm} \mathrm{Cd^{++ }}$. Die Versuchsmedien wurden alle 2 Tage mit den $800 \mathrm{ml}$ fassenden Inkubationsgefäßen gewechselt. Die Toxizität von Cadmium wurde im Hinblick auf folgende Kriterien bewertet: Embryoaktivität, Herzfrequenz, Oberlebensrate bis zum Schlupf, lebensfähiger Schlupf. Die Herzschlagfrequenz und die Ventilationsbewegungen der embryonalen Pectoralflosse waren bei Cadmiumkonzentrationen über $0,5 \mathrm{ppm}$ deutlich beeinflußr. Die Embryonalsterblichkeit war in den Versuchen bis zu einer Konzentration von $1,0 \mathrm{ppm} \mathrm{Cd^{++ }}$ nicht verschieden von den Kontrollen. In den höheren Cadmiumkonzentrationen $(2,0$ und $5,0 \mathrm{ppm})$ nahm die Uberlebensrate bis zum Schlupf sowie der prozentuale Anteil des lebensfähigen Schlupfes mit steigendem Salzgehalt zu. Die Cadmiumaufnahme war deutlich konzentrationsabbängig, lag jedoch in der niedrigsten Salzgehaltsstufe am höchsten. Die unterschiedliche Aufnahme von Cadmium durch Hornhecht-, Herings- und Flundereier wird verglichen und ihre Ursache diskutiert.
\end{abstract}

\section{INTRODUCTION}

During the past years concentrations of heavy metals in certain coastal waters have risen to levels several times higher than those found in unpolluted waters, as determined by Krauskopf (1956), Goldberg (1965), Preston (1973) and others. Concentrations of heavy metals as described by AbduliaH et al. (1972), Abdullah and Royle (1974) and Butterworth et al. (1972) for the Bristol Channel and Eustace (1974) for the Derwent estuary in some instances were of one or two orders

* This study has been financially supported by the Deutsche Forschungsgemeinschaft (Grant No. Ro 380/2). 
of magnitude higher than in unpolluted waters. Exceptionally high values for cadmium (0.05 ppm), copper (0.07 ppm) and lead (0.66 ppm) (up to 180 times that of natural waters) have been recorded in Hongkong waters (CHan et al., 1974).

Elevated concentrations of the above mentioned magnitude are usually restricted to confined localities, largely associated with industrial development (Preston, 1973), indicating that today heavy metal pollution is essentially a problem of inshore waters. Among the heavy metals cadmium as a pollutant represents a real hazard to human health as is documented by the occurrence of the "itai-itai" disease in Japan caused by the ingestion of cadmium contaminated food and water (KOBAYASHI, 1971).

Numerous experiments have proved the acute and chronic toxicity of cadmium to marine animals such as annelids (Brown \& Ahsanulla, 1971), molluscs (CALABrese et al., 1973), crustaceans (O'HARA, 1973a) and to fish eggs (Rosenthal \& Sperling, 1974; Westernhagen et al., 1974; Westernhagen \& Dethlefsen, 1975). Toxicity of cadmium and its accumulation by test organisms was found to depend greatly on the salinity of the sea water in which the experiments were conducted. Detrimental effects of the metal on test organisms were usually less grave in water of high salinity than in a brackish medium.

Investigations on the susceptibility of eggs of inshore spawning teleosts (Clupea barengus, Pleuronectes flesus) showed that these eggs proved to be quite resistant to the toxic action of cadmium (Rosenthal \& Sperling, 1974; Westernhagen et al., 1974; Westernhagen \& Dethlefsen, 1975), and that there existed species specific differences in the accumulation of cadmium from the sea water.

\section{MATERIAL AND METHODS}

Eggs of freshly caught garpike (Belone belone L.) from Travemünde (Baltic Sea) were artificially inseminated in unpolluted $(15 \%, 25 \%$ and $35 \% \mathrm{~S})$ and cadmium polluted water $(25 \% \mathrm{~S})$ at a temperature of $14.7 \mathrm{C}$. After three hours eggs fertilized in uncontaminated water were transferred into $800 \mathrm{ml}$ incubating jars containing natural sea water of the above mentioned salinities (controls) and test solutions of $0.05,0.1$, $0.5,1.0,2.0$ and 5.0 ppm $\mathrm{Cd}^{++}$using $\mathrm{CdCl}_{2}$ as toxicant (Table 1). Incubation temperature was $15^{\circ} \mathrm{C}$. The incubating jars were areated through PVC air tubes with compressed $\mathrm{CO}_{2}$-free air, assuring continuous circulation of the test solution.

Embryonic activity and heart beat, hatching rates and percentage viable hatch were determined. At defined ontogenetic stages eggs were removed and preserved for later cadmium determination. The numbers of eggs in each trial varied from 50 to 150 . Because of expected high mortalities at 2.0 and $5.0 \mathrm{ppm} \mathrm{Cd}$, these trials were stocked with 100 to 150 eggs each compared to 50 to 100 eggs at lower contamination levels. Water was renewed every two days. Dead eggs were counted daily.

Determination of cadmium in water samples and eggs was accomplished by means of flameless atomic absorption spectophotometry using a Perkin Elmer Type 300 equipped with an electrodeless discharge lamp. For determination the samples were treated as described by Westernhagen \& Dethlefsen (1975). 
Table 1

Working levels of cadmium contamination maintained throughout the experiment. * additional trial in $25 \% 0 \mathrm{~S}$, eggs fertilized and incubated in cadmium contaminated water. $\mathrm{n}=$ number of determinations; $\mathrm{x}=$ mean; $\mathrm{s}=$ standard deviation. Temperature range: $14.99-15.11^{\circ} \mathrm{C}$; pH range: $7.93-8.21$

\begin{tabular}{|c|c|c|c|c|c|c|c|}
\hline \multicolumn{2}{|c|}{ Experimental design } & \multicolumn{6}{|c|}{ Working levels } \\
\hline \multirow[t]{2}{*}{$\begin{array}{c}\text { Salinity } \\
(\% \%)\end{array}$} & \multirow[t]{2}{*}{$\begin{array}{l}\mathrm{Cd} \text { concentrations } \\
\text { intended } \\
(\mathrm{ppm})\end{array}$} & \multicolumn{3}{|c|}{$\begin{array}{c}\text { Salinity } \\
(\% 0)\end{array}$} & \multicolumn{3}{|c|}{$\begin{array}{l}\mathrm{Cd} \text { concentrations } \\
\text { determined } \\
(\mathrm{ppm})\end{array}$} \\
\hline & & $\mathrm{n}$ & $\mathrm{x}$ & $\mathrm{s}$ & $\mathrm{n}$ & $\mathrm{x}$ & $\mathrm{s}$ \\
\hline \multirow[t]{7}{*}{15} & Control & 26 & 15.11 & 0.44 & 14 & 0.027 & 0.027 \\
\hline & 0.05 & 28 & 15.12 & 0.39 & 15 & 0.062 & 0.021 \\
\hline & 0.1 & 26 & 15.15 & 0.44 & 14 & 0.124 & 0.040 \\
\hline & 0.5 & 28 & 15.15 & 0.42 & 15 & 0.573 & 0.143 \\
\hline & 1.0 & 28 & 15.19 & 0.41 & 15 & 1.034 & 0,167 \\
\hline & 2.0 & 26 & 15.21 & 0.41 & 13 & 1.991 & 0.358 \\
\hline & 5.0 & 12 & 15.53 & 0.19 & 7 & 4.624 & 0.202 \\
\hline \multirow[t]{7}{*}{25} & Control & 30 & 25.10 & 0.13 & 16 & 0.023 & 0.027 \\
\hline & 0.05 & 30 & 25.13 & 0.11 & 16 & 0.076 & 0.038 \\
\hline & 0.1 & 30 & 25.16 & 0.17 & 16 & 0.130 & 0.045 \\
\hline & 0.5 & 30 & 25.21 & 0.31 & 16 & 0.613 & 0.134 \\
\hline & 1.0 & 28 & 25.19 & 0.16 & 15 & 1.055 & 0.171 \\
\hline & 2.0 & 28 & 25.19 & 0.17 & 15 & 2.004 & 0.253 \\
\hline & 5.0 & 26 & 25.15 & 0.26 & 14 & 4.308 & 0.794 \\
\hline \multirow[t]{6}{*}{$25^{*}$} & 0.05 & 28 & 25.14 & 0.15 & 15 & 0.066 & 0.029 \\
\hline & 0.1 & 30 & 25.16 & 0.13 & 15 & 0.130 & 0.045 \\
\hline & 0.5 & 24 & 25.18 & 0.16 & 13 & 0.548 & 0.119 \\
\hline & 1.0 & 26 & 25.17 & 0.24 & 13 & 1.074 & 0.374 \\
\hline & 2.0 & 26 & 25.12 & 0.14 & 13 & 1.888 & 0.319 \\
\hline & 5.0 & 26 & 25.14 & 0.13 & 14 & 4.270 & 0.719 \\
\hline \multirow[t]{7}{*}{35} & Control & 29 & 34.73 & 0.34 & 15 & 0.035 & 0.030 \\
\hline & 0.05 & 29 & 34.78 & 0.18 & 16 & 0.088 & 0.029 \\
\hline & 0.1 & 28 & 34.81 & 0.21 & 15 & 0.129 & 0.038 \\
\hline & 0.5 & 28 & 34.81 & 0.21 & 15 & 0.581 & 0.167 \\
\hline & 1.0 & 29 & 34.80 & 0.18 & 16 & 0.952 & 0.184 \\
\hline & 2.0 & 29 & 34.77 & 0.17 & 16 & 1.860 & 0.290 \\
\hline & 5.0 & 26 & 34.74 & 0.17 & 14 & 3.988 & 0.789 \\
\hline
\end{tabular}

\section{RESULTS}

\section{Embryonic activity}

Contractions of the heart were first detectible in embryos 8 days old and at that time, except for the $5.0 \mathrm{ppm}$ trials, heart beat did not appear to be affected by the toxicant (Fig. 1). At $5.0 \mathrm{ppm}$ contraction frequency tended to be lower than in the other trials containing less cadmium. With advancing development, differences in heart beat rate at different cadmium contamination levels became more pronounced. This was especially evident at $15 \% \mathrm{~S}$ where 13 day old embryos failed to show any heart 


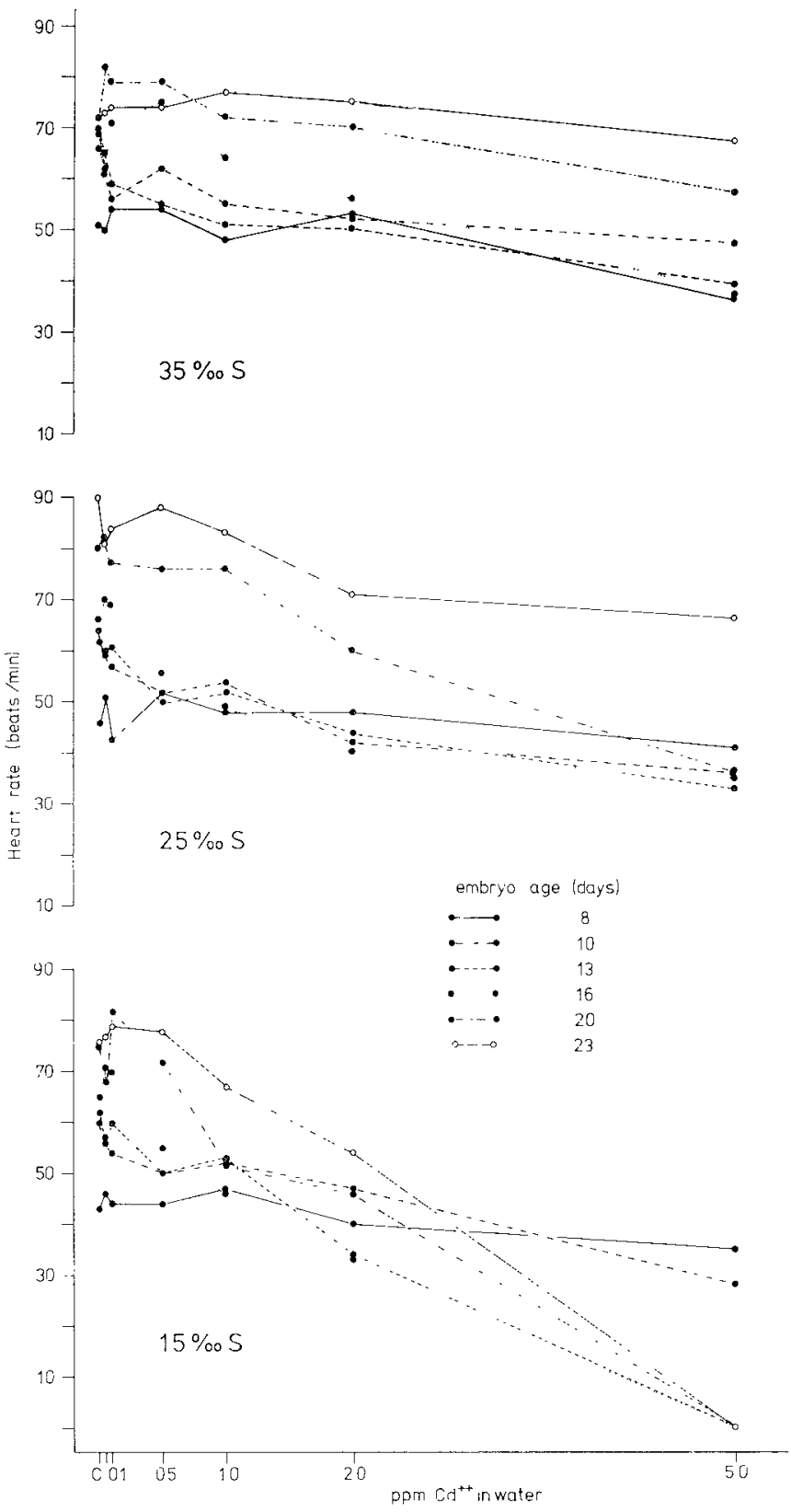

Fig. 1: Belone belone. Heart rate of embryos incubatcd in cadmium contaminated water of different salinities at $15^{\circ} \mathrm{C}$. Each point represents the mean of 10 measurements 
contractions at $5.0 \mathrm{ppm}$ and contraction frequency at 1.0 and $2.0 \mathrm{ppm}$ was much depressed compared to trials with less cadmium. Although not as pronounced as in the $15 \% \mathrm{~S}$ trial, this phenomenon was also detectible at $25 \%$ and $35 \% 0 \mathrm{~S} .20$ day old embryos exhibiting more than 80 heart contractions/min in the controls displayed a heart beat frequency of only 60 and 36 at 2.0 and $5.0 \mathrm{ppm}$. At $35 \% \mathrm{~s}$ inhibiting

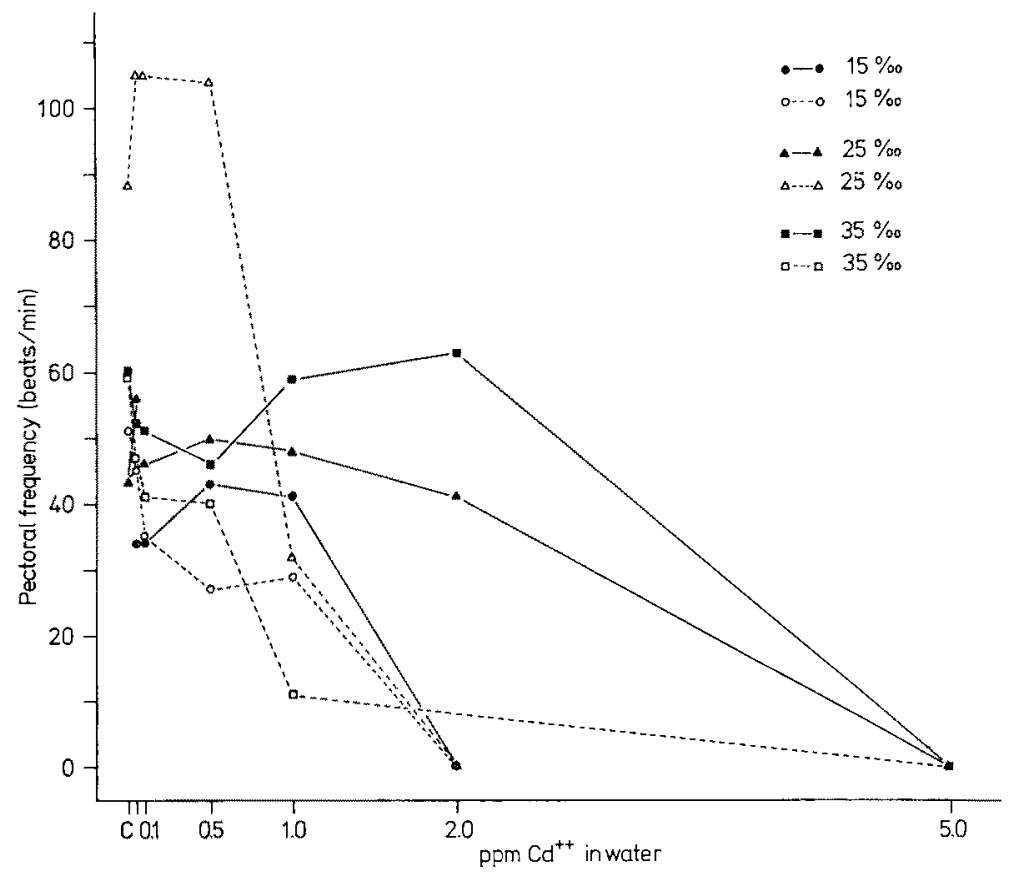

Fig. 2: Belone belone. Frequency of pectoral fin movements of advanced embryos (solid lines: 21 days old; broken lines: 24 days old) incubated in different salinity-cadmium concentrations. Incubation temperature $15^{\circ} \mathrm{C}$. Each point represents the mean of 10 measurements

effects of cadmium on the heart beat frequency of embryos were least severe and although there was still distinct depression of heart activity at 2.0 and $5.0 \mathrm{ppm}$, effects were less pronounced than in trials at $15 \%$ and $25 \% \mathrm{~S}$.

At a certain stage advanced garpike embryos start to circulate the perivitelline fluid in their egg casings (Rosenthal \& Fonds, 1973; Westernhagen, 1974) by means of their pectoral fins. Figure 2 shows effects of cadmium on the pectoral fin activity of 21 and 24 day old prelarvae. As was true for heart activity, pectoral fin activity was completely depressed (at $5.0 \mathrm{ppm}$ ) or greatly reduced in cadmium contaminated water. This was particularly evident in the $25 \% \mathrm{~S}$ trials 24 days after fertilization, in which only at low contamination levels (up to $0.5 \mathrm{ppm}$ ) could high activities be recorded. At $1.0 \mathrm{ppm}$ pectoral fin activity was much reduced and was wanting at 2.0 and $5.0 \mathrm{ppm}$. 


\section{Embryonicsurvivaluntil hatching}

Survival of eggs at cadmium concentrations up to $1.0 \mathrm{ppm}$ was comparable to that in the controls (Fig. 3a). It was only in that $25 \% \mathrm{~S}$ trial in which eggs had been fertilized in cadmium contaminated water that survival was poor (maximum at $0.05 \mathrm{ppm} ; 38 \%$ ) even at lower contamination levels.

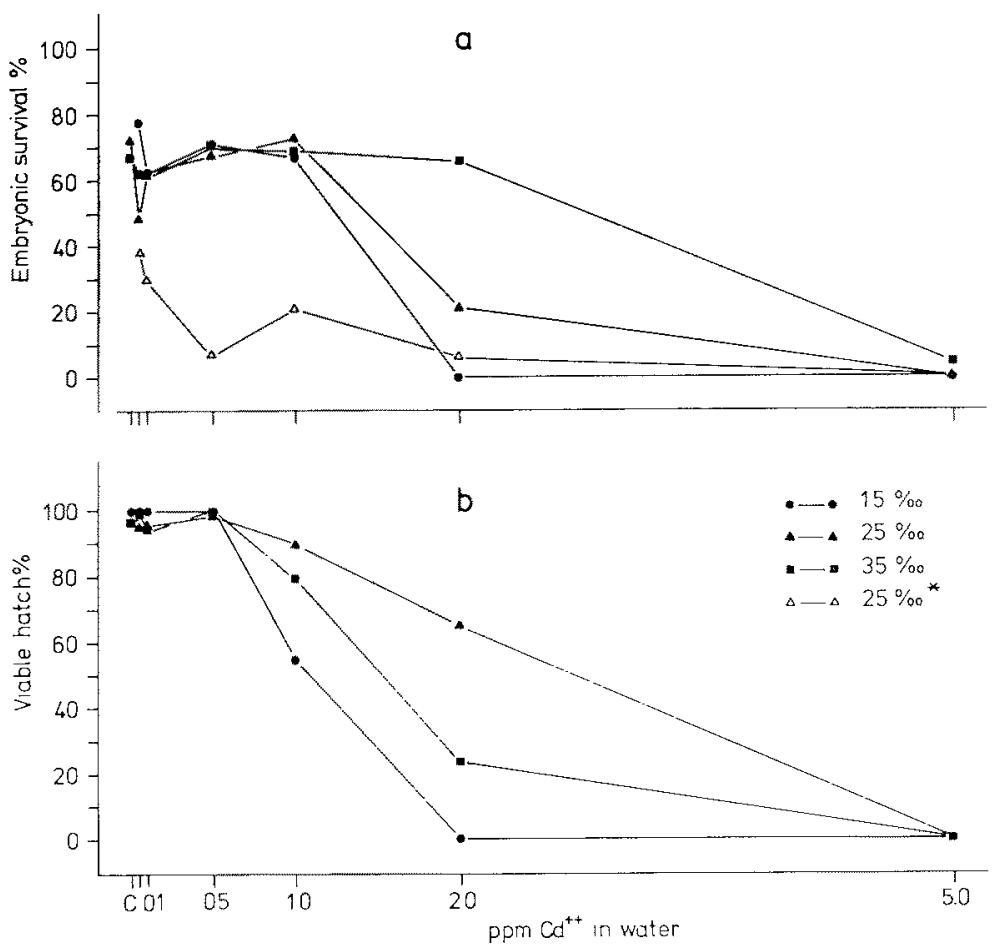

Fig. 3: Belone belone eggs incubated at different salinity-cadmium concentrations. (a) Rates of survival (\% fertilized eggs) until hatching, (b) viable hatch ( $\%$ total hatch). Incubation temperature $15^{\circ} \mathrm{C}$ " Eggs fertilized and incubated in Cd contaminated water

At 2.0 ppm embryonic survival was zero at $15 \% \mathrm{~S}, 20 \%$ at $25 \% \mathrm{~S}$ and above $60 \%$ at $35 \% \mathrm{~S}$. The $5.0 \mathrm{ppm}$ trials did not yield any larvae at $15 \%$ and $25 \% \mathrm{~S}$, at $35 \%$ S a small percentage (4.5\%) of larvae hatched, showing the deleterious influence of cadmium on the embryos being stronger in diluted than in normal sea water.

\section{Viable hatch}

Viable hatch proved to be a finer indication for the toxicity of cadmium than embryonic survival (Fig. 3b). It was only in cadmium concentrations of up to $0.5 \mathrm{ppm}$ that viable hatch was comparable to that of the controls $(94 \%$ to $100 \%)$. At $1.0 \mathrm{ppm}$ 

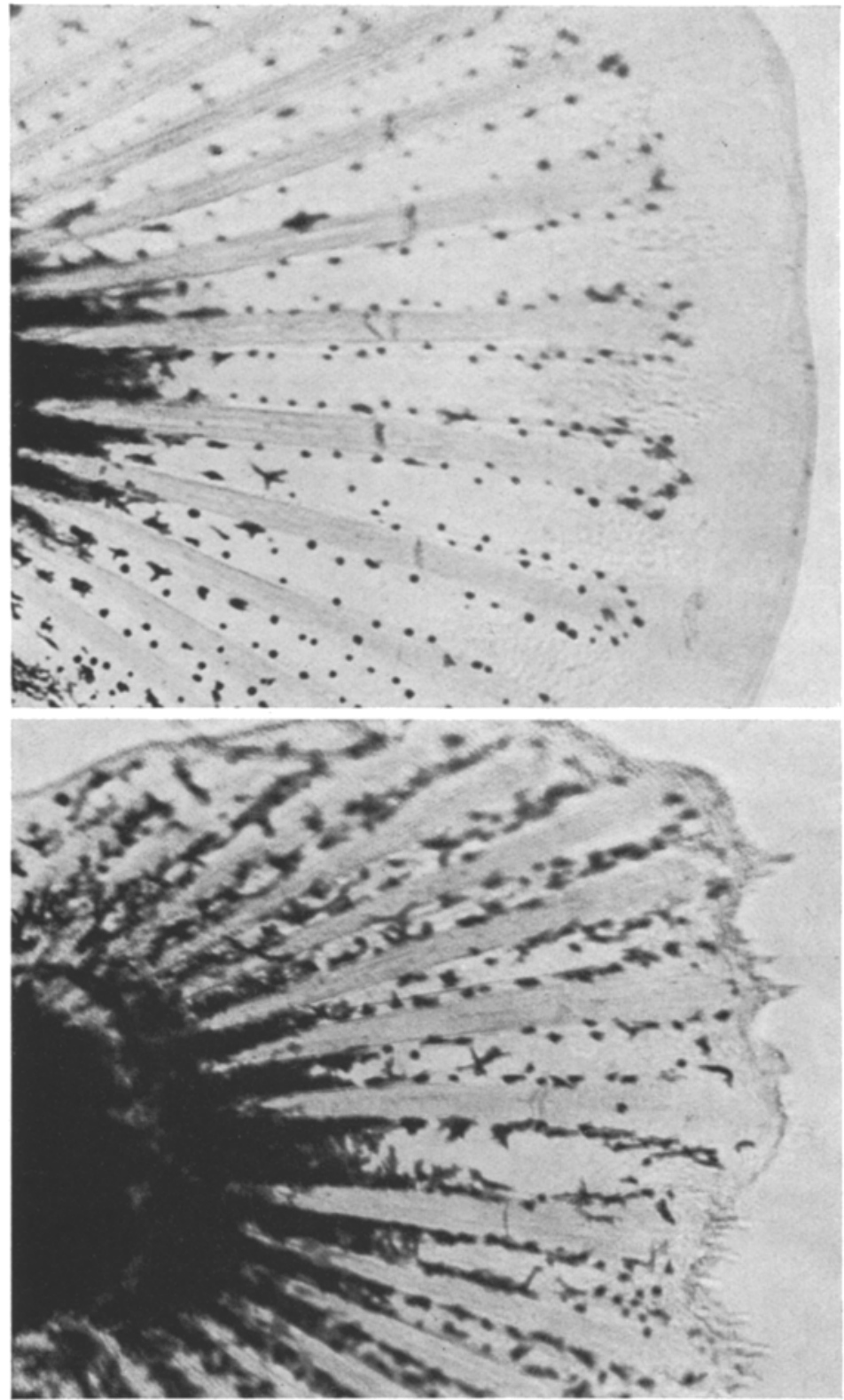

Fig. 4: Belone belone. Serrated caudal fin of a newly hatched larva incubated in cadmium contaminated sea water (bottom) as compared to the undamaged primordial fin of a control specimen (top) 
percentage viable hatch dropped considerably. Newly hatched larvae exhibited serrated or frayed primordial and caudal fins (Fig. 4) not commonly found in control individuals. At $2.0 \mathrm{ppm}$ no viable larvae were obtained at $15 \% \mathrm{~S}$. In none of the salinities tested did at $5.0 \mathrm{ppm}$ cadmium contamination hatch any viable larvae. The few larvae derived from the $35 \% \mathrm{~S}$ trial were all crippled.

\section{Cadmium uptakduring embryonic development}

Amount of cadmium accumulated by garpike eggs during embryogenesis under exposure to cadmium ions is shown in Figure 5. Initial cadmium uptake after exposure had to be fairly rapid, because highest metal concentrations in eggs were, except for a few trials, recorded at the first day after fertilization. Prolonged exposure did not lead to increasing cadmium content in eggs. In fact cadmium content in eggs decreased steadily throughout the incubation period, reaching lower values after 24 days than those recorded on the first day.

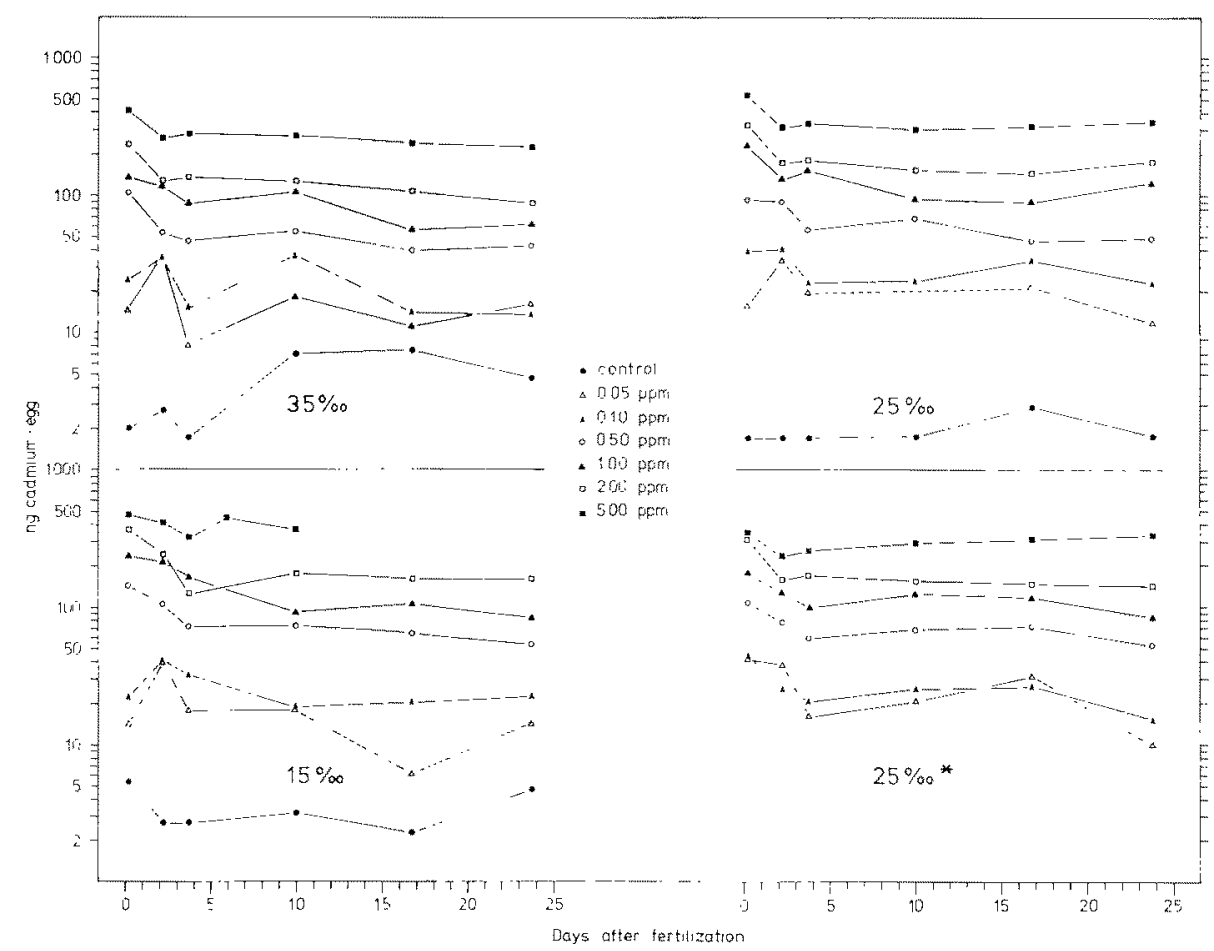

Fig. 5: Belone belone. Mean cadmium content of eggs during the course of incubation period in relation to cadmium concentration and salinity of the incubation medium. Incubation temperature $15^{\circ} \mathrm{C}$. Eggs fertilized and incubated in cadmium contaminated water. Each point is based on 5 determinations. Broken line: one value missing 
Maximum levels attained depended on the initial concentrations employed. Accumulation was higher at $15 \% \mathrm{~S}$ (Fig. 5) than at $25 \%$ and $35 \%$ S. No differences in contamination levels could be detected between the two $25 \% \mathrm{~S}$ series, the eggs in one

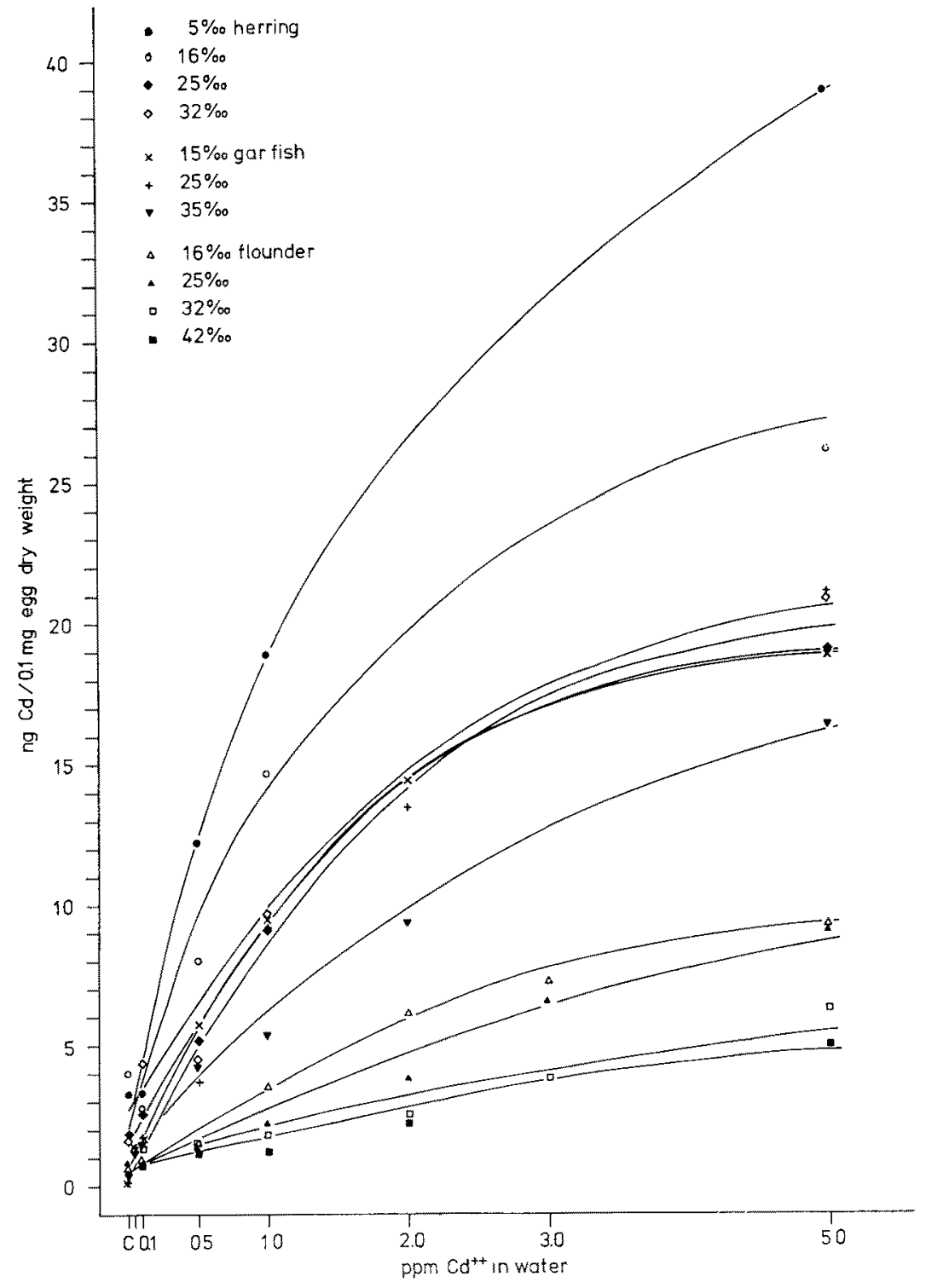

Fig. 6: Accumulation of cadmium in demersal (Clupea barengus, Belone belone) and pelagic (Pleuronectes flesus) marine fish eggs in relation to cadmium concentration and salinity of the incubation medium 
of which had been fertilized in contaminated water, while the eggs of the other series were fertilized in an uncontaminated medium.

Newly hatched larvae at all cadmium-salinity combinations contained only small amounts of cadmium.

In Figure 6 maximum amounts of cadmium found in garpike eggs are compared on a $0.1 \mathrm{mg}$ dry weight basis with values recorded from herring (WESTERNHAGEN et al., 1974 ) and flounder eggs (WeSTERnHAgen \& DethleFsen, 1975). Herring eggs appear to accumulate slightly more cadmium than do garpike eggs incubated at respective salinities. Both egg types show much higher accumulation values than are found in flounder eggs.

\section{DISCUSSION}

The experiments indicate that toxic action of cadmium on the developing eggs of garpike (Belone belone L.) is dependent on the salinity of the incubating medium. Embryonic activity as well as embryonic survival and viable hatch were most adversely affected by cadmium ions during exposure of eggs in diluted sea water. There was a high-low relationship between detrimental effects of the metal and salinity of the incubating medium. The same results have been found by WESTERNHAGEN et al. (1974) when testing the reaction of developing herring eggs to cadmium ions.

They assumed an interaction between $\mathrm{Cd}^{++}$and $\mathrm{Ca}^{++}$ions, which in diluted sea water with less $\mathrm{Ca}^{++}$ions would lead to relatively higher amounts of the toxic $\mathrm{Cd}^{++}$ to be incorporated into the egg shell (chorion). The apparent interaction between $\mathrm{Cd}^{++}$ and $\mathrm{Ca}^{++}$ions had been pointed out previously by KoBayashi (1971) and MaIjKovic \& Branica (1971). On the same basis the extremely high cadmium susceptibility of fresh water teleosts described by Pickering \& Henderson (1966), Bail (1967) and Cearley \& Coleman (1974) can be explained: freshwater having a much lower content of $\mathrm{Ca}^{++}$ions than sea water.

Several other authors working with heavy metals in sea water, for example OLSON \& HARREL (1973) could show that the acute toxicity of mercury, copper and chromium on the bivalve Rangia cinneata increased with decreasing salinity and the same was stated by RoEsIJADI et al. (1974) working on the toxic action of mercury on the porcelain crab Petrolisthes armatus. In contrast to these findings WeSTERNHAGEN $\&$ DeTHLEFSEN (1975) were not able to show a relationship between toxicity of cadmium and salinity of the incubating medium when working with the eggs of flounder, Pleuronectes flesus, which at all salinities were distinctly less susceptible to the toxic action of cadmium than were herring or garpike eggs under the same conditions. At all salinities tested $(16 \%-42 \% \mathrm{~S})$ there was considerable viable hatch $(18 \%$ at $42 \% \mathrm{~S})$ of flounder larvae.

A possible explanation for the different reactions of demersal (herring, garpike) and pelagic (flounder) eggs is given when looking at Figure 6. Eggs incubated at low salinities have accumulated more cadmium than when kept at comparable contamination levels at high salinities. This phenomenon is known for crustaceans exposed to cadmium under various salinity conditions as could be shown by O'Hara (1973b) 
working with Uca pugilator and HuTCHESON (1974) investigating cadmium uptake by Callinectes sapidus.

Cadmium contamination of herring and garpike eggs as shown in Figure 6 is several times higher than that of flounder eggs incubated under the same toxicant conditions. Maximum values for flounder eggs depending on the salinity of the incubating medium (16\%-32\%), range from 6 to $9 \mathrm{ng} \mathrm{Cd} / 0.1 \mathrm{mg}$ egg dry weight. It should be considered though that incubation temperatures were not the same for all three species.

Table 2

Surface to volume ratio of fish eggs: Belone belone, Pleuronectes flesus, Clupea barengus

\begin{tabular}{|ccc|}
\hline Species & $\begin{array}{c}\text { Salinity } \\
(\%)\end{array}$ & Surface to volume ratio of fish eggs $\left(\mathrm{mm}^{-1}\right)$ \\
\hline Garpike & 15 & 1.81 \\
& 25 & 1.91 \\
Flounder & 35 & 1.85 \\
Herring & 16 & 5.47 \\
& 5 & 4.40 \\
& 16 & 4.58 \\
& 25 & 4.71 \\
& 32 & 5.24 \\
\hline
\end{tabular}

Maximum contamination levels for herring eggs for the same salinity range vary from 19 to $26 \mathrm{ng} \mathrm{Cd} / 0.1 \mathrm{mg}$ egg dry weight, and garpike eggs show similar values between 16.5 and $21 \mathrm{ng} \mathrm{Cd} / 0.1 \mathrm{mg}$ egg dry weight. Slightly higher values for herring eggs (at $15 \%$ and $35 \%$ S) are probably due to the higher surface/volume ratio of these eggs (Table 2), herring eggs having a diameter of about $1 \mathrm{~mm}$, while garpike eggs are much bigger (diameter approx. $3 \mathrm{~mm}$ ).

Although the surface/volume ratio of flounder eggs is similar to that of herring eggs (Table 2) cadmium content of the pelagic flounder eggs is much lower than would be expected from these data. Thus uptake and accumulation of cadmium can only to a certain extent depend on the surface/volume ratio, but appears to be directly related to physical and chemical properties of the egg membrane which actually is the site of cadmium uptake (RosentHal \& SPERLING, 1974; Westernhagen et al., 1974). As evident from Figure 5 uptake was completed shortly after exposure, which suggests binding of cadmium to a complexing agent, the capacity of which at a certain cadmium concentration is set, otherwise further accumulation throughout the experiment would be expected.

The thick chorion of herring ( $\sim 16 \mu$; BRAUM, personal communication) and garpike eggs $(20-25 \mu)$ provide more material and complexing agent to accumulate cadmium than flounder eggs with their thin egg membrane $(\sim 1.8 \mu$; LöNNING \& SOLEMDAHL, 1971). As mentioned by WesternhAgen \& Dethlefsen (1975) an additional capacity for cadmium accumulation by herring eggs appears to be the adhesive covering the surface of these eggs. Table 3 presents accumulation values of garpike, her- 
Table 3

Cd-accumulation by fish eggs incubated at different cadmium-salinity concentrations

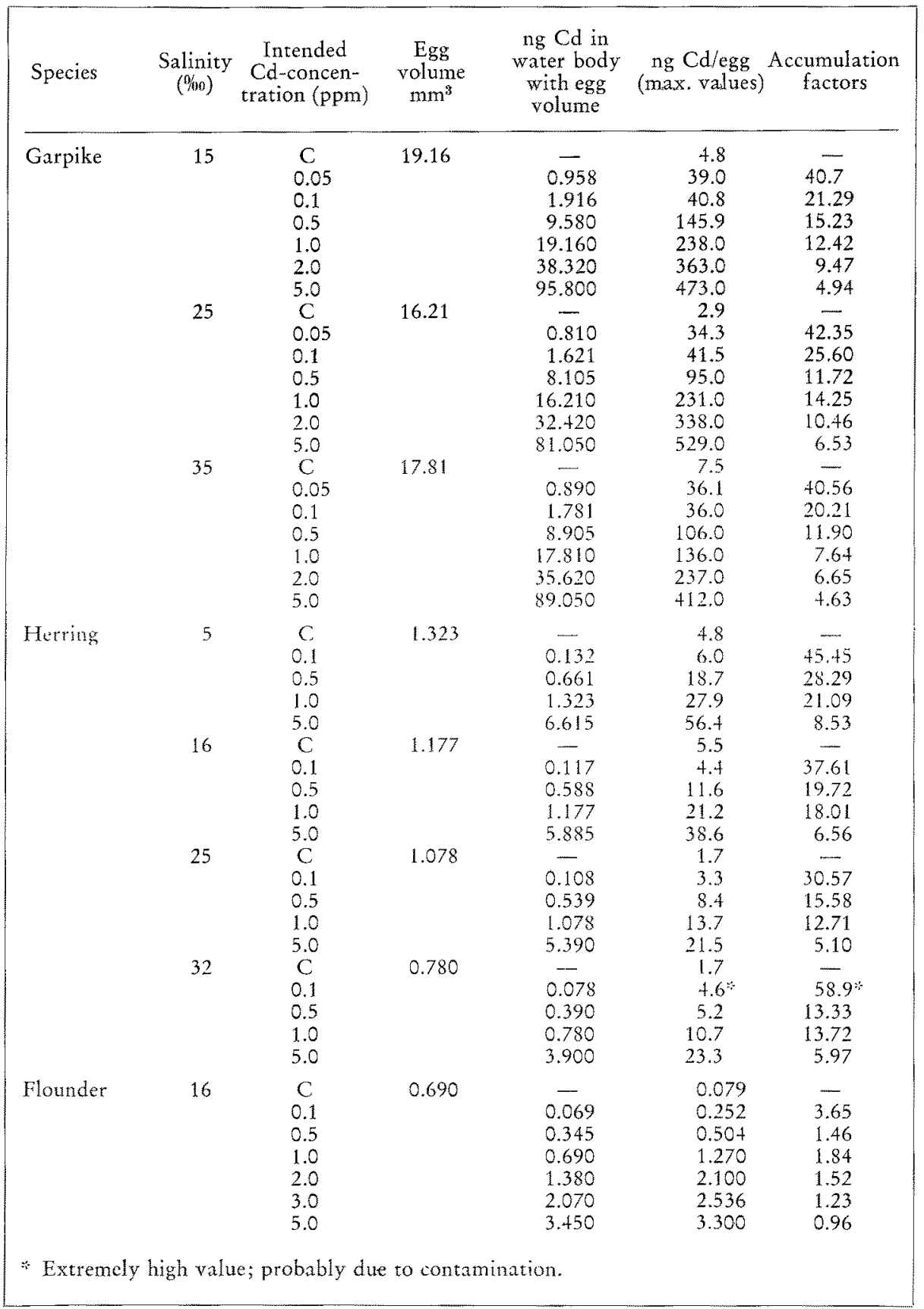


ring and flounder eggs incubated under different salinity-cadmium concentrations. The accumulation factor is calculated by dividing the amount of cadmium found in one egg by the theoretical amount of cadmium in a water body having the volume of one egg at the respective salinity. Thus garpike eggs incubated at $15 \% \mathrm{~S}$ and $0.05 \mathrm{ppm}$ cadmium contained 40.7 times more cadmium than is present in a water body with the volume of one egg $\left(19.16 \mathrm{~mm}^{3}\right)$.

The high accumulation factor of garpike eggs $(>20)$ incubated at $0.1 \mathrm{ppm} \mathrm{Cd^{++ }}$ is even surpassed by herring eggs (30.57-45.45). As suggested by WESTERNHAGEN \& DetHLEFSEN (1975), this is probably due to complex forming mucopolysaccharides on the sticky egg surface. From Table 3 it becomes apparent that there is only considerable accumulation of cadmium in the demersal egg of garpike and herring. Flounder eggs take up only very minute amounts of cadmium.

In all three species there exists the same general pattern for the uptake of cadmium from surrounding water. The lower the ambient metal concentration, the higher the accumulation factors (Table 3 ). At $5.0 \mathrm{ppm}$ cadmium concentration in flounder eggs was not higher than in the surrounding medium.

From the above it becomes conceivable to understand the mechanism of cadmium accumulation in fish eggs as binding of the metal to one or several agents the capacity of which is limited. Thus high ambient cadmium concentrations, although leading to high absolute contamination, cause overloading of binding capacities on the egg surface, giving rise to relatively low accumulation factors.

The combined results of the present and the foregoing studies of ROSENTHAL \& Sperling (1974), Westernhagen et al. (1974) and Westernhagen \& Dethlefsen (1975) conducted on marine fish eggs exposed to cadmium enable us to understand the mechanism of cadmium accumulation by fish eggs as a binding of the metal to one or several agents on or inside the chorion. Highest cadmium concentrations were always reached shortly after exposure. Further exposure did not lead to higher accumulation values, suggesting that the binding capacity of the chorion is limited.

The chorion of fish eggs with its binding agents acts as a protecting barrier that prevents cadmium from entering the egg proper. Thick egg membranes as found in herring and garpike eggs accumulate up to 10 times more cadmium than the thin chorion of flounder eggs. Thus at high ambient cadmium concentrations seepage of metal through the metal overloaded egg membrane, a mechanism suggested by Danielit \& Davies (1951) for the reaction of metals on cell surfaces, and consequent intoxication of the embryo is more likely in fish eggs with thick egg membranes. This would explain the relatively low susceptibility of flounder eggs to the toxic action of cadmium as described by Westernhagen \& Dethlefsen (1975) compared to reactions of herring and garpike eggs under the same conditions.

\section{SUMMARY}

1. Eggs of Baltic Sea garpike (Belone belone L.) were incubated in normal and cadmium contaminated sea water $(0.05,0.1,0.5,1.0,2.0,5.0 \mathrm{ppm})$ at $15 \%, 25 \%$ and $35 \% \mathrm{~S}$ and $15^{\circ} \mathrm{C}$. 
2. Embryonic heart beat and frequency of pectoral fin movements in prelarvae was found to be greatly depressed by cadmium concentrations of more than $0.5 \mathrm{ppm}$.

3. Embryonic survival and viable hatch were unaffected in cadmium concentrations of 1.0 and $0.5 \mathrm{ppm}$, respectively. At high cadmium concentrations (2.0 and $5.0 \mathrm{ppm}$ ) there were greater embryonic survival and viable hatch at high than at low salinities.

4. Cadmium content of eggs was found to be generally higher in lower salinities than in more saline water at comparable cadmium concentrations.

5. Accumulation factors of cadmium in eggs were inversely proportional to the ambient cadmium concentration. Highest accumulation factors of more than 40 were recorded at $0.05 \mathrm{ppm} \mathrm{Cd}$. At high cadmium concentrations accumulation factors were only around 5 .

Acknowledgements. We are indebted to G. Fürstenberg, T. HudTW AlCKer, J. KuINCKMANN, E. Ropers and G. VILLA-Ruiz for expert technical assistance and M. BlaKe for advice on the preparation of the manuscript.

\section{LITERATURE CITED}

Abdullah, M. J. \& Royle, L. G., 1974. A study of the dissolved and particulate trace elements in the Bristol Channel. J. mar. biol. Ass. U.K. 54, 581-597.

- - \& Morris, A. W., 1972. Heavy metal concentration in coastal waters. Naturc, Lond. $235,158-160$.

Bat.L, I. R., 1967. The toxicity of cadmium to rainbow trout (Salmo gairdnerii Richardson). Wat. Res. 1, 805-806.

Brown, B. \& Ahsanullah, M., 1971. Effect of heavy metals on mortality and growth. Mar. Pollut. Bull. 2, 182-187.

Butterworth, J., Lester, P. \& Nickless, G., 1972. Distribution of heavy metals in the Severn estuary. Mar. Pollut. Bull. 3, 72-74.

Calabrese, A., Collier, R. S., Nelson, D. A. \& Mclnnes, J. R., 1973. The toxicity of heavy metals to embryos of the American oyster Crassostrea virginica. Mar. Biol. 18, 162-166.

Cearley, J. E. \& Coleman, R. L., 1974. Cadmium toxicity and bioconcentration in largemouth bass and bluegill. Bull. environ. Contam. Toxicol. 11, 146-151.

Chan, J. P., Cheung, M. T. \& Li, F. P., 1974. Trace metals in Hongkong waters. Mar. Pollut. Bull. 5, 171-174.

Danielli, J. F. \& Davies, J. T., 1951. Reactions at interfaces in relation to biological problems. Adv. Enzymol. 11, 35-89.

Eustace, I. J., 1974. Zinc, cadmium, copper and manganese in species of finfish and shellfish caught in the Derwent estuary, Tasmania Austr. J. mar. Freshwat. Res. 25, 209-220.

Goldberg, E. D., 1965. Minor elements in sea water. In: Chemical Oceanography. Ed. by J. P. Riley \& G. Skirrow. Acad. Press, New York, 1, 163-196.

Hutcheson, M. S., 1974. The effect of temperature and salinity on cadmium uptake by the blue crab, Callinectes sapidus. Chesapeake Sci. 15, 237-241.

Kobayashi, J., 1971. Relation between the "itai-itai" disease and the pollution of river water by cadmium from a mine. Adv. Wat. Pollut. Res. 1, 1-32.

KRAUSKOPF, K. B., 1956. Factors controlling the concentrations of thirtecn rare metals in sea-water. Geochim. cosmochim. Acta 9, 1-32.

Lönning, S. \& Solmmdahl, P., 1972. The relation between thickness of chorion and specific gravity of eggs from Norwegian and Baltic flatfish population. FiskDir. Skr. (Havunders.) $16,77-88$. 
Maljkovic, D. \& Branica, M., 1971. Polarography of seawater. II. Complex formation of cadmium with EDTA. Limnol. Oceanogr. 16, 779-785.

O'HARA, J., 1973a. The influence of temperature and salinity on the toxicity of cadmium to the fiddler crab, Uca pugilator. Fish. Bull. U.S. 71, 149-153.

- 1973b. Cadmium uptake by fiddler crabs exposed to temperature and salinity stress. J. Fish. Res. Bd Can. 30, 846-848.

Olson, K. R. \& Harrel, R. C., 1973. Effect of salinity on acute toxicity of mercury, copper and chromium for Rangia cuneata (Pelecypoda, Mactridae). Contr. mar. Sci. 17, 9-13.

Pickering, Q. H. \& Henderson, C., 1966. The acute toxicity of some heavy metals to different species of warmwater fishes. Int. J. Air Wat. Pollut. 10, 453-463.

Preston, A., 1973. Heavy metals in British waters. Nature, Lond. 242, 95-97.

Roesijadi, G., Petrocelli, S. R., Anderson, J. W., Presley, B. J. \& Sims, R., 1974. Survival and chloride ion regulation of the porcelain crab Petrolisthes armatus exposed to mercury. Mar. Biol. 27, 213-217.

Rosenthal, H. \& Fonds, M., 1973. Biological observations during rearing experiments with the garfish Belone belone. Mar. Biol. 21, 203-218.

- \& Sperling, K. R., 1974. Effects of cadmium on development and survival of herring eggs. In: The early life history of fish. Ed. by J. H. S. Blaxter. Springer, Berlin, 383-396.

Westernhagen, H. von, 1974. Incubation of garpike eggs (Belone belone LinNé) under controlled temperature and salinity conditions. J. mar. biol. Ass. U.K. 54, 625-634.

- Rosenthal, H. \& Sperling, K. R., 1974. Combined effects of cadmium and salinity on development and survival of herring eggs. Helgoländer wiss. Meeresunters. 26, 416-433.

- \& Dethlefsen, V., 1975. Combined effects of cadmium and salinity on development and survival of flounder eggs. J. mar. biol. Ass. U.K. 55 (in press).

First author's address: Dr. H. von WesternhAGEN

Biologische Anstalt Helgoland (Zentrale)

D-2 Hamburg 50

Palmaille 9

Federal Republic of Germany 